\title{
Guest editorial: Nontraditional Credit in U.S. Agriculture
}

\section{Forward to Special Issue by Tom Worth, Director of the Resource and Rural Economics Division of the USDA's Economic Research Service:}

\begin{abstract}
We are pleased to recognize the efforts of the economists who contributed to the Agricultural Finance Review's special issue on Nontraditional Credit in US Agriculture. The group's efforts were led by Brady Brewer (Purdue University) and Jennifer Ifft (Kansas State University) who circulated the original call that resulted in these 11 articles from 34 different authors. USDA provided financial support - through a cooperative agreement - for non-USDA authors not otherwise fully supported by their home agency or organization.
\end{abstract}

Understanding the sources of credit for agricultural production is critical for regulators and policymakers concerned with the stability of financial institutions, agricultural production and the welfare of farmers. Research in this special issue sheds new light on nontraditional farm credit by exploring the scope and range of this lending, the services provided to farmers, and the role this credit plays in the agricultural economy.

Several of the articles included herein draw heavily on the Agricultural Resource Management Survey (ARMS) and the Farm Income and Wealth data series, two of USDA's premiere data products. Every year since 1996, ARMS has asked a nationally representative sample of farmers and ranchers a series of detailed questions about their outstanding loan balances, including questions on lender type that underlie one definition of a nontraditional lender. ARMS-based aggregate measures of nontraditional lender activity are included in the sector balance sheet within the Farm Income and Wealth data series. Stretching back even longer (to 1960), USDA's farm sector balance sheet provides loan balances from regulatory and administrative sources alongside an "individuals and others" line item for debt and reflecting the size of the nontraditional sector over time. This research, in addition to highlighting the role of nontraditional lenders, explicitly underlines the value of USDA's commitment to long term data collection in order to understand the structure and dynamics of the agricultural sector.

Motivation The financing of production agriculture has become increasingly diverse, in terms of credit delivery and terms, as well as lender type or source of credit. Yet, most agricultural finance research still focuses on traditional agricultural lending relationships. The goal of this special issue is to advance the literature on non-traditional finance in US agriculture and lay a foundation for future research, while also providing insights for farm managers, industry and policymakers. Navigating complex financing options is an integral component of modern farm management. From a policy perspective, financial regulators, such as regional Federal

The authors are grateful to the USDA ERS for supporting this special issue. All papers in this special issue received funding for authors that are not employees of the US Department of Agriculture, except MacDonald $e t$ al. and Lyons and Takach. The authors would also like to thank Anil Giri and Jeff Hopkins for providing important support and insights from the inception of this special issue, as well as several farm lenders, both traditional and non-traditional, who gave their time to help us better understand current agricultural credit market conditions. The findings and conclusions in this publication are those of the author(s) and should not be construed to represent any official USDA or US Government determination or policy.

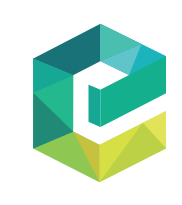

Agricultural Finance Review Vol. 82 No. 2, 2022 pp. 205-213
(c) Emerald Publishing Limited DOI 10.1108/AFR-04-2022-187 
Reserve Banks, track the financial performance of agricultural banks (banks where farm loans comprise 25 percent or more of total loans) and the United States Department of Agriculture (USDA) tracks farm financial well-being, including making updates to the US farm sector income and balance sheet forecasts and estimates three times a year. Policymakers need accurate information on the volume and risk associated with nontraditional finance, but publicly available data sources may not encompass all types of nontraditional lenders (Fiechter and Ifft, 2020b).

Research on non-traditional finance is still nascent. The studies in this special issue help to define the scope of non-traditional finance and describe how it serves the needs of different types of producers. While some non-traditional lenders face a similar level of financial regulation as traditional lenders, different farm lenders have different levels of financial regulation, which has been referred to as a "regulatory mosaic" (Barry, 1995). While some have speculated that non-traditional finance may be increasing financial risk in the farm sector (Newman and Tita, 2017), this relationship does not always hold (Ifft et al., 2017). Several of the articles in this issue examine the potential risks posed by users of nontraditional finance to lenders.

What is non-traditional finance? Most attempts at defining non-traditional finance rely on either regulation or loan origination and lender characteristics. However, most definitions are not based on lending history or experience: vendor credit is likely one of the oldest forms of credit. Sherrick et al. (1994) provide a definition that focuses on vendor finance: whether the primary relationship between the lender and borrower is provision of credit. The USDA Economic Research Service (ERS) estimates total farm sector debt and has a category called "individuals and others" that would be consistent with a definition of non-traditional lenders as lenders who are not subject to public reporting of debt volumes [1]. Fiechter and Ifft (2020a) define non-traditional lenders as entities who offer credit outside of the "traditional" or most prevalent type of farm lending: relationship-lending with a loan officer based in a local bank or Farm Credit System branch. This definition encompasses the growing group of collateralbased and non-bank lenders serving production agriculture and can be broken down into three categories: vendor finance, high-volume branchless lenders and collateral-based lenders. All of these definitions may be confounded by traditional lenders offering nontraditional lending products, such as AgDirect loans offered by Farm Credit System lenders [2]. While any categorization is inherently imperfect, all of these definitions are useful in understanding the current agricultural credit landscape.

The articles in this special issue use various methods and datasets. The first set looks at how non-traditional finance is used by different types of borrowers: beginning farmers, women farmers, socially disadvantaged farmers, dairy farmers, farmers serving direct and local markets, cannabis farmers, etc. The second set of articles considers non-traditional finance and farm business risk for FSA borrowers, Chapter 12 bankruptcy cases and farmer cooperatives. The third set of articles considers non-traditional finance and credit markets, specifically collateral-based lenders, secondary markets and perceived competition by commercial banks.

\section{Borrowers}

Research has shown that farmers who borrow from non-traditional lenders tend to be younger and more indebted (Brewer et al., 2019). However, there has been little research into how non-traditional credit serves particular types of operations. "On the money: characterizing banking and lending in the California cannabis industry" (Plakias et al., 2021) describe how a specific and heavily regulated sub-sector utilized non-traditional lenders to finance production. Due to the regulatory environment of the cannabis industry along with the perceived riskiness of the cannabis industry, traditional lenders were unable to serve this growing market. This paper found positive spillover effects of the cannabis industry to the 
financial sector, such as increased deposits and loans, along with an overall increase in economic activity in other sectors of the economy. There may be opportunities for traditional lenders to provide credit to this market if banking regulations are eased to allow for loans to be made to businesses that produce controlled substances. These results have implications beyond cannabis farming, as there are many sub-sectors that may want to use traditional lenders but are unable to, due to how new the sector is and the speed at which regulation and traditional banking are able to adjust.

"The role of nontraditional lending for socially disadvantaged and financially stressed farmers" (McDonald et al., 2022) uses USDA Agricultural Resource Management Survey (ARMS) data to show that socially disadvantaged farmers (defined as non-white or female) have certain characteristics that distinguish themselves from non-socially disadvantaged farmers. Socially disadvantaged farmers had lower value of production, fewer operators, fewer acres, received less government payments, fewer assets and were more leveraged. Of these differences, the only characteristic that was associated with a higher probability for a socially disadvantaged farmer to use a non-traditional lender was lower assets. This may be due to a variety of reasons, such as higher business risk profiles or the capital structure of farms. This paper also examined the association between financial stress and loan utilization. It was found that as farms become more leveraged, the probability of using only a nontraditional lender decreased. This shows that farmers are not using non-traditional lenders as a lender of last resort, at least not for the entirety of the farming operation. Future work could try to determine the factors driving lending access and choice of lending institution for socially disadvantaged and financially stressed farmers. Such research would provide valuable insight into how and why socially disadvantaged and financially stressed farms participate in non-traditional credit markets.

Nadonlyk and Hartarska (2022) also use ARMS data in their study on "Nontraditional lenders and access to local agricultural credit markets by beginning and female farmers." They link the farms sampled in ARMS to county-level branch density of Farm Credit System, banks and credit unions and alternative financial services [3]. They then use several econometric models to regress different loan outcomes on credit access. Generally, results varied by beginning, female and non-beginning farm operators and, in some cases, lending outcomes were related to credit access. For example, for women farmers there may be a substitutionary relationship between access to banks and credit unions and use of nontraditional finance. These results support the need for future research on local credit access and market structure and illustrate why it is important for future research to consider the heterogeneous impacts of credit access.

The Thilmany et al. (2022) study "Unique Financing Strategies Among Beginning Farmers and Ranchers: Differences among Multi-Generational and Beginning Operations" compares beginning farmer financing strategies to those of established operations. Beginning farmers can find it more difficult to secure credit from some traditional lenders, because they are less likely to have established sales and collateral for secured loans. Nontraditional financing tools may help beginning farmers to start, build and sustain their businesses. This study uses ARMS data to compare financing patterns of operations where: (1) all operators are beginning, (2) there is a mix of beginning and established operators and (3) all operators are established. The study found that operations where all operators are beginning farmers generally rely more heavily on non-traditional lending sources than established operations or operations with some beginning farmers. The financing patterns imply that some beginning farms are highly dependent on personal relationships, input supplier and credit card financing and could benefit from financing options that are more flexible, easier to access, or require less collateral than traditional sources.

The Stevens (2022) case study "Nontraditional credit in the Wisconsin dairy industry" found that $80 \%$ of case study participants borrowed from at least one non-traditional lender, 
AFR

82,2

208 largely vendor finance for equipment or machinery purchases. Overall, non-traditional loans made up $17 \%$ of total borrowing. Attitudes towards non-traditional lenders relative to traditional lenders varied greatly among the surveyed farmers. About half were indifferent between getting credit from non-traditional and traditional lenders, while the other half appeared to prefer traditional lenders. In total, $60 \%$ of farmers reported that non-traditional credit was more convenient, while half reported that they needed larger loans than a traditional lender could provide. Overall, this study highlights the prevalence of nontraditional lenders in the dairy industry and introduces several interesting hypotheses for future study. For example, non-traditional lenders may be targeting dairy farms that are too large or complex for a local branch lender.

\section{Farm business risk}

Non-traditional lenders may be exposed to more default risk than traditional lenders. "An economic analysis of nontraditional lending in Chapter 12 bankruptcy cases" (Rabinowitz and Secor, 2022) examines the extent to which non-traditional lenders were able to recoup payment of secured debt in Chapter 12 bankruptcy cases. This paper finds that traditional lenders with secured debt were able to recoup a greater portion of their loans. However, nontraditional lenders held a significantly smaller share of the bankrupt farmers' debt [4]. This shows that if non-traditional lenders were to become bigger in terms of share of debt for Chapter 12 bankruptcy, non-traditional lenders may be more at risk than their traditional counterparts. It would be informative to extend this study to cases where the court ultimately does not relieve the debtor of their loan obligations, as these cases may impact the credit quality of the lending institutions.

Along the same lines, "Assessing the financial condition and accounts receivable risk among US farmer cooperatives" (Mashange and Briggeman, 2022) shows that a specific type of non-traditional lender, farmer cooperatives, are able to absorb a substantial increase in bad debt expense. This paper shows that the financial position of these farmer cooperatives has steadily improved over time and that many cooperatives have the capacity to extend more credit than they currently do. This paper recommends that cooperatives should operate more like a traditional bank by monitoring their accounts receivable to retained earnings ratio. This would provide a similar measure to a traditional banks' Tier 1 capital ratio [5], which is a measure of the financial strength of a lending institution.

Ahrendsen et al. (2022) use data from FSA direct loan borrowers to consider the relationship between probability of default (borrower risk) and use of non-traditional credit either from (1) intermediate vendor financing, largely from machinery and equipment vendors and (2) short-term vendor financing, largely from variable input vendors. Findings suggest borrowers using short-term vendor financing have a $22-25 \%$ higher probability of default, compared to $9 \%$ higher for borrowers using intermediate vendor financing. FSA borrowers are not representative of US farmers, but are much more likely to represent creditconstrained borrowers, based on the explicit objectives of FSA loan programs. Creditconstrained borrowers are of particular interest in studies of non-traditional finance, given that some non-traditional lenders are not subject to public reporting. These findings suggest that some types of non-traditional credit may be used more by financially stressed or vulnerable farm operations.

\section{Credit markets}

"Strategic behavior of nontraditional lenders in agricultural credit markets" (Tetteh et al., 2022) conducted in-depth case studies with five non-traditional lenders: one was engaged in vendor 
finance, while the other four would be considered collateral-based lenders. The insights highlighted in the paper, especially into collateral-based lenders, make an important and unique contribution to current understanding of non-traditional finance. These lenders are generally not subject to public reporting and information on their activities is difficult, if not impossible, to acquire through farm surveys. The collateral-based lenders interviewed in this study had diverse strategies and target markets, but their approach was generally built on "supply gaps" in current agricultural credit markets, for e.g. producers with a high share of rented land. Lending standards were generally comparable to traditional lenders; when collateral-based lenders worked with more financially stressed producers, additional safeguards were put into place and the lenders were more involved in farm management. Further, many of the lenders acquired funds from traditional lenders or worked in partnership with traditional lenders.

Lyons and Takash (2022) use Farmer Mac data in their study titled "A profile of nontraditional agricultural real estate lender activity in the secondary market." Farmer Mac is the main secondary agricultural real estate lender. This study looked at the volume of loans purchased from non-traditional agricultural real estate lenders (NARELs, as defined in the article) and provided important insights into the characteristics and objectives of these lenders. NARELs are found to currently make up over one-third of Farmer Mac's Farm and Ranch portfolio by volume and one-quarter by count. This paper finds no observable differences between non-traditional and traditional lenders with regards to borrower credit characteristics, loan approval rates, interest margins and loan performance. The lack of differences may partially be explained by Farmer Mac's lending standards. The study does find significant differences between loan volumes and variable rate product use. While the study does not find that NARELs necessarily take on riskier loans, it does show the growth of these lenders and their higher use of a riskier lending product. Overall, this study provides a baseline for further study using Farmer Mac data, as well as increasing understanding of non-traditional farm real estate lending.

The growth in volume of short-term credit from non-traditional lenders suggests that there could be increased competition between commercial banks and non-traditional lenders. Kuethe et al. (2022) explore this issue in "Perceived Competition in Agricultural Lending: Stylized Facts and an Agenda for Future Research." The authors use information from the Federal Reserve Bank of Chicago's Land Values and Credit Conditions Survey to construct a novel measure of commercial banks' perceived competition from the Farm Credit System and from non-traditional lenders. Their empirical analysis shows that these two sources of competition have different relationships with commercial bank lending terms, loan portfolio riskiness and expected loan volumes. One interesting insight is that higher commercial bank loan defaults are correlated with higher perceived competition from non-traditional lenders, but the opposite relationship holds for perceived competition from Farm Credit System lenders. These findings highlight the need for further research on agricultural lending market competition that considers both traditional and non-traditional lenders.

\section{Conclusions and implications}

The studies in this special issue provide a broad perspective on farm lending that should inform and inspire future research on agricultural credit markets. While relationship or branch-based lending is still the foundation for credit to production agriculture, there are a large and diverse number of lenders that provide credit through multiple channels. These channels seem to be continually broadening in terms of both volume and the number of players. A better understanding of non-traditional lenders and borrowers is important for policymakers and credit market participants alike.

The research in this issue shows that non-traditional lenders offer a diverse range of financial products to farmers. This increases the total supply of credit and likely increases farmer welfare. Several of the papers in this issue show that non-traditional lenders extend 
AFR

82,2

credit to what may otherwise be underserved segments of the market. Fiechter and Ifft (2020b) suggest that non-traditional lenders may contribute around $10-20 \%$ of all agricultural credit, based on estimates that collateral-based lenders may make up 1-2\% of all farm lending and that branchless high-volume lenders may contribute $8-10 \%$ of farm lending. However, Fiechter and Ifft (2020a, b and c) likely underestimated the volume of vendor finance. We now believe vendor finance might make up $10-12 \%$ of all credit to production agriculture based on (1) industry anecdotes that $10 \%$ of variable expenses are purchased using vendor credit and (2) the predominance of implement manufacturers and dealers in machinery lending (Byers and Ifft, 2021). Jointly, these estimates suggest that financing by non-traditional sources, or outside of traditional farm lending relationships, could be as high as $25 \%$ of farm lending [6], albeit with some of this share from lenders who publicly report debt volumes and are hence accounted for in USDA farm sector debt estimates. This is not intended to be a precise estimate but to demonstrate how nontraditional lenders are a significant part of the agricultural credit landscape.

It has been hypothesized that non-traditional lenders increase the risk to agricultural credit markets by allowing risky borrowers to become overly leveraged. However, current data and research does not conclusively support this claim. Systemic risk is limited by the market share currently held by non-traditional lenders and the notion that non-traditional borrowers have a higher risk of default may not apply in all instances. Ahrendsen et al. (2022) show important correlations between higher probability of default and non-traditional lenders, especially those who supply short-term inputs. This additional risk would pose a challenge for regulators, especially for lenders not subject to public reporting. While there is some evidence that certain types of loans by non-traditional lenders are associated with riskier borrowers, there is evidence that non-traditional lenders are well positioned for this increased risk. Mashanga and Briggeman (2022) found that cooperatives are well capitalized and thus could extend more credit than they currently do. This brings a key point that while non-traditional lenders may cater to riskier borrowers for certain loan products, they also bring additional capital. Any analysis that examines how non-traditional lenders change the risk profile of the agricultural credit markets must account for the additional capital they bring.

We conclude with three primary recommendations for future research. First, novel data sources are needed to inform policy and management research on non-traditional finance, especially for future research on underserved and socially disadvantaged farmers. Second, future empirical research on non-traditional lending should use methodologies that support a causal interpretation of results. Third, research on emerging trends in agricultural credit markets would benefit from greater consideration or analysis of non-traditional lenders.

Future research on agricultural credit markets, including non-traditional finance research, should explore novel data sources. While farm management datasets have yielded some important insights (i.e. Brewer et al., 2019; Fiechter and Ifft, 2020c), these datasets are limited in number and represent a specific group of largely-Midwestern midsize to large commercial producers (Kuethe et al., 2014). Likewise, USDA farm survey data (ARMS) yielded important insights in several studies in this special issue, but data on non-traditional lenders in ARMS are heavily skewed towards implement-dealer lenders (Ifft et al., 2017). Tetteh et al. (2022) highlight the dearth of data on collateral-based lenders, while Lyons and Takash (2022) provide evidence that various types of non-traditional lenders play a significant role in farm real estate lending. The findings of Ahrendsen et al. (2022) suggest the importance of studying vendor finance for short-term inputs, while Thilmany et al. (2022) suggest that beginning farmers pursue diverse financing strategies and these may not be well reflected in farm survey data. Further, current farm financial data sources tend to reflect producers that contribute the majority of agricultural production and are hence inherently less reflective of groups that contribute a small share of production, such 
as socially disadvantaged farmers [7]. Given the growth of farm policies focused on underserved and socially disadvantaged producers [8], novel data are needed to fully understand their financing practices and needs, including the use of non-traditional lenders and/or financing strategies.

There is a need for empirical research on non-traditional finance based on causal inference. The studies in this special issue provide many policy and management relevant insights but do not make causal claims. This special issue does support several hypotheses that would benefit from robust, causal analysis. For example, while these and other studies have established a link between financial stress and some types of non-traditional lending (e.g. Ahrendsen et al., 2022), we cannot make claims about whether these relationships increase or decrease financial stability. Likewise, it would be interesting to test whether there is a causal link between access to different lender types, including non-traditional lenders, and beginning farm survival. Future research could also explore factors driving the movement of farmers between traditional and non-traditional lenders and the relative role of demand versus supply factors.

Finally, consideration of non-traditional lending is important when analyzing ongoing and emerging trends in agricultural credit markets. One such trend is the ongoing consolidation of Farm Credit System Associations and the decreasing number of community banks (Kim and Katchova, 2021). The latter trend may be creating opportunities for nontraditional lenders. Recent trends that merit further research include the impact of COVID-19, record-high government payments and potential interest rate increases on both traditional and non-traditional lenders. Another is the deepening of the secondary market for agricultural loans. While we are not aware of any estimates of the size of the secondary market, Farmer Mac has seen its farm real estate portfolio volume more than double over the last decade (USDA ERS, 2022) and this may be an area of interest for new entrants [9]. The implications of structural change and continued farm consolidation (Whitt et al., 2020) are also of interest: in the long term, some separate financing lines that traditional and nontraditional lenders provide may become less relevant, as large organizations typically hold credit lines that can cover a wide range of short- and long-term capital needs. Likewise, some farms are now large enough that individual lenders cannot handle the associated lending risk and must cooperate with other lenders on "syndicated loan agreements." Farm Credit System institutions held over US\$23bn in these type of loans by the end of 2020 (Farm Credit Administration, 2021). Finally, there are multiple examples of increased external investment into the agricultural sector, whether for technology, farmland ownership or farm lending [10]. The degree to which these investments drive innovation and long-term change is an open question, but regardless, credit markets will continue to evolve. Non-traditional lenders will play a key role in this evolution.

Brady Brewer

Department of Agricultural Economics, Purdue University, West Lafayette, Indiana, USA

Jennifer Ifft

Department of Agricultural Economics, Kansas State University, Manhattan, Kansas, USA, and

Nigel Key USDA Economic Research Service, Washington, District of Columbia, USA

\section{Notes}

1. ERS estimates use publicly reported loan data when available; the estimate of debt held by "individuals and others" is based on farm survey data (Briggeman et al., 2012). 
AFR

82,2

212

2. https://www.agdirect.com/

3. Nadonlyk and Hartarska (2022) define alternative financial services as "AFS are financial services provided outside traditional banking institutions and proxy here for the insufficient banking services in the county [. . .] AFS include rent-to own agreements, pawnshops, refund anticipation loans, some subprime mortgage loans, car title loans, payday loans and private moneylenders."

4. Debt refers to all forms (secured, priority and unsecured) of lending institutions debt.

5. The Tier 1 capital ratio is the equity capital of a bank (or firm) to its total risk-weighted assets.

6. This estimate excludes loans from individuals.

7. https://www.ers.usda.gov/topics/farm-economy/socially-disadvantaged-beginning-limitedresource-and-female-farmers-and-ranchers/

8. https://www.ers.usda.gov/agriculture-improvement-act-of-2018-highlights-and-implications/ beginning-socially-disadvantaged-and-veteran-farmers-and-ranchers/

9. For example, see https://www.linkedin.com/company/farmhold/about/

10. For example, investments from venture capital, pension funds or individuals who are not farm operators.

\section{References}

Ahrendsen, B.L., Dodson, C.B., Short, G., Rainey, R.L. and Snell, H.A. (2022), "Beginning farmer and rancher credit usage by socially disadvantaged status", Agricultural Finance Review. doi: 10. 1108/AFR-05-2021-0060.

Barry, P.J. (1995), The Effects of Credit Policies on US Agriculture, American Enterprise Institute.

Brewer, B.E., Bergtold, J.S., Featherstone, A.M. and Wilson, C.A. (2019), "Farmers' choice of credit among the farm credit system, commercial banks, and nontraditional lenders", Journal of Agricultural and Resource Economics, Vol. 44 No. 2, pp. 362-379, doi: 10.22004/ag.econ.287984.

Briggeman, B.C., Koenig, S.R. and Moss, C.B. (2012), "US farm debt: the role of ARMS”, Agricultural Finance Review. doi: 10.1108/00021461211250483.

Byers, L. and Ifft, J. (2021), "Recent trends in nontraditional lending", Risk and Profit Conference, Kansas State University Department of Agricultural Economics, Manhattan Kansas, August 19-20.

Farm Credit Administration (2021), "2020 annual report of the farm credit administration regulator of the farm credit system", available at: https://www.fca.gov/template-fca/about/ 2020AnnualReport.pdf.

Fiechter, C. and Ifft, J. (2020a), "What makes nontraditional finance nontraditional?", Farmdoc Daily, Vol. 10 No. 50.

Fiechter, C. and Ifft, J. (2020b), "How big is nontraditional finance?", Farmdoc Daily, Vol. 10 No. 55.

Fiechter, C. and Ifft, J. (2020c), "Vendor finance in the northeast dairy industry", Farmdoc Daily, Vol. 10 No. 60.

Ifft, J., Kuethe, T. and Patrick, K. (2017), Nontraditional Lenders in the US Farm Economy, Regional Research Committee NC-1177 (formerly NC-1014): Agricultural and Rural Finance Markets in Transition.

Kim, K.N. and Katchova, A. (2021), "Unlikely players in agricultural lending market: what are the consequences of agricultural bank acquisitions", 2021 Annual Meeting, Agricultural and Applied Economics Association, Austin, Texas (No. 312749), August 1-3.

Kuethe, T.H., Briggeman, B., Paulson, N.D. and Katchova, A.L. (2014), “A comparison of data collected through farm management associations and the agricultural resource management survey", Agricultural Finance Review. doi: 10.1108/AFR-09-2014-0023. 
Kuethe, T., Fiechter, C. and Oppedahl, D. (2022), "Perceived competition in agricultural lending: stylized facts and an agenda for future research", Agricultural Finance Review, Vol. 82 No. 2, pp. 417-437. doi: 10.1108/AFR-04-2021-0045.

Lyons, G.A. and Takach, J. (2022), "A profile of nontraditional agricultural real estate lender activity in the secondary market”, Agricultural Finance Review, Vol. 82 No. 2, pp. 397-416. doi: 10.1108/ AFR-06-2021-0081.

Mashange, G. and Briggeman, B.C. (2022), "Assessing the financial condition and accounts receivable risk among US farmer cooperatives”, Agricultural Finance Review, Vol. 82 No. 2, pp. 344-358. doi: 10.1108/AFR-06-2021-0080.

McDonald, T.M., Law, J., Giri, A.K. and Subedi, D. (2022), "The role of nontraditional lending for socially disadvantaged and financially stressed farmers", Agricultural Finance Review, Vol. 82 No. 2, pp. 247-267. doi: 10.1108/AFR-06-2021-0072.

Nadolnyak, D. and Hartarska, V. (2022), "Nontraditional lenders and access to local agricultural credit markets by beginning and female farmers", Agricultural Finance Review, Vol. 82 No. 2, pp. 268-284. doi: 10.1108/AFR-06-2021-0073.

Newman, J. and Tita, B. (2017), “America's farmers turn to bank of John Deere”, Wall Street Journal.

Plakias, Z., Jodlowski, M., Giamo, T., Kavousi, P. and Taylor, K. (2021), "On the money: characterizing banking and lending in the California cannabis industry", Agricultural Finance Review, Vol. 82 No. 2, pp. 214-246. doi: 10.1108/AFR-06-2021-0075.

Rabinowitz, A.N. and Secor, W.G. (2022), "An economic analysis of nontraditional lending in Chapter 12 bankruptcy cases”, Agricultural Finance Review, Vol. 82 No. 2, pp. 329-343. doi: 10.1108/AFR06-2021-0088.

Sherrick, B.J., Sonka, S.T. and Monke, J.D. (1994), "Nontraditional lenders in agricultural credit markets", Agribusiness, Vol. 10 No. 4, pp. 341-357.

Stevens, A.W. (2022), "Nontraditional credit in the Wisconsin dairy industry", Agricultural Finance Review, Vol. 82 No. 2, pp. 310-328. doi: 10.1108/AFR-05-2021-0068.

Tetteh, I., Boehlje, M., Giri, A.K. and Sharma, S. (2022), "Strategic behavior of nontraditional lenders in agricultural credit markets", Agricultural Finance Review, Vol. 82 No. 2, pp. 379-396. doi: 10.1108/AFR-06-2021-0074.

Thilmany, D., Bauman, A., Hadrich, J., Jablonski, B.B.R. and Sullins, M. (2022), "Unique financing strategies among beginning farmers and ranchers: differences among multigenerational and beginning operations", Agricultural Finance Review, Vol. 82 No. 2, pp. 285-309. doi: 10.1108/ AFR-05-2021-0070.

Whitt, C., Todd, J.E. and MacDonald, J.M. (2020), America's Diverse Family Farms: 2020 Edition, Economic Information Bulletin No. 220, United States Department of Agriculture Economic Research Service. 